\title{
Sociosemiotic Frontiers. Achievements, Challenges, and Prospects of Converging Semiotic and Social
}

\begin{abstract}
Ivan Fomin
National Research University Higher School of Economics, Faculty of Social Sciences, School of Politics and Governance. Institute of Scientific Information for Social Sciences of the Russian Academy of Sciences, Center for Advanced Methods of Social Studies and Humanities
\end{abstract}

Received: July 2020; Accepted: September 2020

\begin{abstract}
This article reviews the achievements and challenges that appear from attempts to integrate the studies of the semiotic and the social. Based on an analysis of the projects of Social Semiotics, semiotic sociology, and sociosemiotic approach to culture, it is suggested that the development of sociosemiotics could be represented (both retrospectively and prospectively) as trajectories of two frontiers. These are the frontier of sociosemiotic material and the frontier of sociosemiotic methodology. The frontier of sociosemiotic material represents how social semiotics progresses in broadening its scope by extending the set of materials which are considered as objects of sociosemiotic analysis. The frontier of sociosemiotic methodology describes how semiotic tools are integrated with other methodologies of social studies. The article shows what key steps have already been made to transcend the boundaries between social and semiotic research, and what directions are possible for further integration of social and semiotic sciences.
\end{abstract}

Keywords: intentional acts, logonomic systems, methods of social science, multimodality, Schutz, semiotics, semiotics of action, semiotics of behavior, semiotic institutionalism, semiotic sociology, social meaning, social semiotics, sociosemiotic approach to culture, sociosemiotics, systemic functional linguistics, Tartu-Moscow School, Weber

In 1978, Michael Halliday published a book under the title Language as Social Semiotic: The Social Interpretation of Language and Meaning, giving an initial impetus to the systematic exploration of the interface of semiotic and social. Talking about social semiotic, Halliday was focused on how functional and meaningful aspects of human social life are expressed in communication and language. Thus, a convergence appeared between semiotic system (langue) and semiotic product (parole) on the one hand, and social system and social action on the other. Importantly, Halliday's project aspired to go beyond the usual interpretations of society and language as two domains that are connected merely by juxtaposition. Halliday insisted that in their very essence language and society are an inseparable unity of the mutually supplementing elements of human existence that are the social and the semiotic. (Halliday 1978, 4).
Halliday's approach was further developed and reinterpreted by Bob Hodge and Gunther Kress in their book Social Semiotics (1988), in which they showed that the convergence of social and semiotic is relevant not only for language, but for all the modes of human communication. This conceptualization arose as a result of the further synthesis of ideas from the field of critical social theories (primarily Marxism) and Hallidayan system-functional linguistics. Speaking about the subject area of Social Semiotics, Hodge and Kress explained that it is concerned with the entirety of human semiosis which is "an inherently social phenomenon in its sources, functions, contexts and effects" (Hodge, Kress 1988, 261). By taking this stance, they essentially elaborated, at a new level, the ideas of Charles W. Morris, who, 50 years earlier, noted that the common property of the subjects of all 
humanities and social sciences is that their subjects are inherently semiotic (Morris 1938, 2).

Of course, Charles Morris was not the only thinker who spoke about social semiotics before the very term of social semiotics was coined. In particular, it was Ferdinand de Saussure who put at the very foundation of structuralist thought the quasi-sociological concepts of language as a "social fact" (Saussure 1995, 21), language as a "social institution" (Saussure 1995, 32), and language as a "treasure" belonging to the community (Saussure 1995, 30). Furthermore, Saussure's definition of semiology essentially emphasized the sociological aspect of semiological research (studying "the life of signs within society" (Saussure 1995, 33)). At the same time, a reciprocal incentive to the convergence of semiotic and social studies can also be found in the very foundations of social science, as in the definition of sociology proposed by Max Weber the discipline is characterized essentially as a quasi-semiotic enterprise. In particular, Weber suggests that the aim of sociology consists in the interpretive understanding of subjectively meaningful behavior (Weber 1985, 542).

Many other researchers in the twentieth century have also made significant strides in describing and explaining how some semiotic and social forms are related. In particular, one of the most important steps in this direction was taken by Ludwig Wittgenstein, who formulated in his Philosophical Investigations a fundamental tenet on the relationship between "language-games" (forms of language) and "forms of life" (Wittgenstein 2017, §19-23). Furthermore, John Austin and John Searle have shown how language forms function as forms of social action (e.g.: Austin 1962; Searle 1989). In addition, one has to mention a whole galaxy of structuralist and (post)-structuralist thinkers who in one way or another addressed the problem of "the life of signs within society" (e.g.: Barthes 1957; Foucault 1966). Finally, there emerged a wide variety of approaches to the analysis of discourses, focusing on how social circumstances limit and predetermine the use of language and how language supports social structures and power relations (e.g. Caldas-Coulthard, Coulthard 1996).

However, despite all this active work at the crossroads of social and semiotic research, the progress in this area has been uneven to date. A number of important results have been obtained and many insightful concepts developed, but the task of systematically studying the relations between forms of communication and forms of social life is, in fact, only just starting to be solved. In this situation, I think, it is important to critically review how semiotic and social have been methodologically converging and to explore what can be done to further advance this process. So, in this paper I will try to show what key steps have already been made to transcend the disciplinary boundaries between the methodologies of social studies and semiotic research, and what challenges still have to be resolved. ${ }^{1}$ Moreover, in the final section I will also attempt to identify possible trajectories for further integration of social and semiotic sciences.

Of course, in one article it is hardly possible to cover all the points in which semiotic and social studies converge. I am therefore mostly focusing on three projects that, in the most explicit way, aim at building social-semiotic interfaces. ${ }^{2}$ Those projects are Hodge's and Kress's systemi-functional Social Semiotics, "neo-structuralist" semiotic sociology pioneered by Risto Heiskala, and sociosemiotic approach to culture developed by Anti Randviir.

\section{CORRELATING LINGUISTIC AND SOCIAL IN SYSTEMIC FUNCTIONAL GRAMMAR}

As I have already mentioned above, the development of Social Semiotics as an independent research discipline is associated with the name of M. A. K. Halliday. In his book Language as Social Semiotic he articulated the task of systematically considering language as a social phenomenon and not just a sign system (Halliday 1978, 1-4). In particular, Halliday acknowledged that he interpreted the famous Saussurean formula "language is a social fact" in a sense that is not quite Saussurean. He recalled John Rupert Firth's saying that a language of a particular community is "a function of la masse parlante, stored and residing in the conscience collective" (Halliday 1978, 1 , original emphasis) and insisted that language, being "a product of social process" (Halliday 1978, 1), "is as it is because of the functions it has evolved to serve in people's lives" (Halliday 1978, 4). He also emphasized that it is by "acts of meaning" that people exchange information, goods and services, "act out the social structure", affirm statuses and roles, and produce shared systems of knowledge and values (Halliday 1978, 1).

Thus, Halliday has in fact identified a new research object that lies at the intersection of social and linguistic sciences. This subject comprises the functional and meaningful aspects of social life, as those aspects manifest themselves in human communication and language. This is what Halliday calls social semiotic and it is in order to account for the complexity of this compound that he proposed his systematics of metafunctions that would structure not only the language, but also the entire social life. Such metafunctions include 1) the ideational function (the function of expressing the speaker's experience), 2) the interpersonal function (the function of expressing relations among participants in the situation), 3) the textual function (the enabling function of forming textually cohesive and contextually relevant messages) (Halliday 1978, 45-46, 50, 112, 117, 130).

Halliday's approach enabled the distinction of

1 In many respects this article develops the ideas that were formulated in Russian in (Fomin, Ilyin 2019).

2 For a much broader review of various schools, branches, and currents of sociosemiotics see (Cobley, Randviir 2009). 
analytical types of communication situations, and makes it possible to bring the actual speech practices into the domain of the social and return them back into the domain of the linguistic. There are three aspects to the linguistically significant features of language use in each communicative situation: 1) field of discourse ("what is taking place?"-the institutional setting of language use), 2) tenor of discourse ("who is taking part?"-the relationship between participants), 3) mode of discourse ("what part the language is playing?"-the organization of the semiotic texture). These three aspects correspond to the three metafunctions of language. The constellation of the variables of field, tenor, and mode determines the register, i.e. "the range within which meanings are selected and the forms which are used for their expression" (Halliday 1978, 31-35).

In general, the systemic functional grammar developed by Halliday became one of the key elements in the conceptual core of Social Semiotics. His most important contribution to the interface of social and semiotic studies was the attempt to systematically interpret language as a broad social practice, not just as a sign system. As he distinguished "language as reflection", "language as action" and "language as texture" (Halliday 1978, 187), Halliday succeeded in showing how language as a communicative practice works not only as a linguistic phenomenon, but also as a social one. By acknowledging the correlation between linguistic structures and the structures of the context, he discovered the isomorphism of the semiotic and social that makes social structures meaningful and linguistic structures effective. However, this crucial step forward had significant limitations, as Halliday's work was based almost exclusively on the analysis of language material. He was able to isolate the functions of language and show that many of them are social, but the institutional aspects of communication have actually been left in the shadow.

\section{INTERACTING REFERENTIAL AND SOCIAL MEANINGS IN SOCIAL SEMIOTICS}

While Halliday seems to be the first one to coin the term social semiotic (in singular), he mainly used it to refer to the subject matter of his system-functional grammar. As the name of a special interdisciplinary field, this word combination was introduced by Halliday's students Bob Hodge and Gunther Kress who published the book Social Semiotics (in plural) in 1988. The very usage of social semiotics in plural made it echo the names of some scientific disciplines (mathematics, economics, physics, etc.). Moreover, it showed that the authors went beyond the Hallidayan linguistic agenda by offering a frame that could fit all the social semiotic phenomena (including language, but not limited to it). According to Hodge and Kress, Social Semiotics "studies all human semiotic systems, since all these are intrinsically social in their conditions and content" (Hodge, Kress 1988, 261).

An important terminological addition to the toolkit of
Social Semiotics was made in the 1990s, when Gunther Kress and Theo van Leeuwen proposed the term multimodality in order to grasp the fact that sociosemiotic phenomena always appear as a product of multiple different sign systems combined, which may be pictorial, audial, gestural, written, etc. (Kress, van Leeuwen 1996, 2001). Those non-linguistic "languages" were called modes. The concepts of mode and multimodality gained popularity across various social disciplines. Today, multimodality is used not only as a term referring to the multiplicity of modes in sociosemiotic material, but also as a label for a very fragmented inter-disciplinary current, integrated only by the aim of analyzing how complexes of multiple meaning-making resources are used in different contexts. In particular, the principle of multimodality was productively imported into conversation analysis, ethnographic research, systemic-functional discourse analysis, social interaction analysis, etc. (Jewitt et al. 2016). Thus, the introduction of multimodality can be seen as one of the main achievements of Social Semiotics in terms of bridging semiotic and social sciences. At the same time, however, one can also can see a challenge here, as in a way, the "multimodality studies" may have even eclipsed Social Semiotics as such.

Bob Hodge and Gunther Kress proposed to distinguish between a mimetic plane and semiotic plane of social semiotic phenomena (Hodge, Kress 1988, 262), suggesting that (1) on the mimetic plane each phenomenon refers to a certain version of reality, while (2) on the semiotic plane each phenomenon also implies a certain social semiotic event which involves some senders, recipients and signs used by them. In many ways, this dichotomy is reminiscent of Halliday's distinction between ideational and interpersonal linguistic metafunctions, as well as the separation of semantics and pragmatics in Charles Morris's theory of signs (Morris 1938).

The social semiotic theory developed by Hodge and Kress quite clearly implied that the social semiotic analysis should be based on a critical stance. The core elements of their theory were rooted in the Marxist vision of social dynamics and influenced by the ideas of Mikhail Bakhtin (cited as Valentin Voloshinov), Antonio Gramsci, and Louis Althusser. In particular, the theory suggested that social relations "are constituted by relations of power (order and subordination) and solidarity (cohesion and antagonism), with these dimensions typically both complementary and opposed" (Hodge, Kress 1988, 266). According to Hodge and Kress, all sign systems in human society are subject to these two principles. In order to model the interactions between social groups, Hodge and Kress introduced the concept of logonomic systems. Such systems are defined as sets of rules "prescribing the conditions for production and reception of meanings" (Hodge, Kress 1988, 4). Those rules would constrain who can produce and who can receive signs, about what topics, in what circumstances, and with what modalities.

Summing up, when it comes to the convergence 
of the semiotic and social, the theorists of Social Semiotics made two key achievements. The first of them consists in the fact that Hodge and Kress boldly declared that (not just language, but) all human semiosis is to be studied in Social Semiotics. By doing so they have built an entirely new theoretical perspective and have proposed a frame that would position sociosemiotic analysis as one of the most potent methodologies for transdisciplinary research in social studies and humanities. However, of course, designing such a transdisciplinary methodology was not enough: actually turning it into a transdisciplinary practice was another task altogether, which is very challenging itself.

The second achievement of Social Semiotics was in fact the introduction of multimodality, i.e. the concept that (not just language, but) all human interactions can be analyzed as different semiotic systems (modes). Thus, Social Semiotics made an important step towards transcending the limitations of Hallidayan language-focused studies of the "social interpretation of meaning". However, even though proclaiming this ambitious stance, Hodge and Kress were still quite limited in the scope of their actual analyses. In fact, they were mostly focused on the communicative practices that were mostly "obviously communicative", while political, economic, financial and other social interactions (especially macrointeractions) were probably implied as semiotic ones, but almost never actually considered as such.

\section{SEMIOTISED REALITY AND CULTURE IN THE SOCIOSEMIOTIC STUDIES OF TARTU-MOSCOW SCHOOL}

Even though Social Semiotics as a specific toolkit of analytical concepts is associated mostly with the works of Halliday, Hodge, Kress, and other theorists of systemic-functional linguistics, the development of the broader sphere of social semiotics obviously cannot be reduced only to this tradition. (I use capitalized and non-capitalized versions to distinguish between the two ${ }^{3}$ ). In particular, some other important contributions to the construction of social-semiotic interface was provided by the Tartu-Moscow School of the semiotics of culture. It is especially interesting that the very term social semiotic (sotsialnaya semiotika) appeared in the works of Yuri Lotman (Lotman 1975b, 20; Lotman 1976, 292-293; Zolyan 2017) in the same period that Michael Halliday published his first works about "language as social semiotic" (Halliday 2007[1975]), even though it is quite unlikely that any communication between the two theorists existed at that time (Zolyan 2019, 406).

Lotman, however, did not really provide any detailed account of the notion of sotsialnaya semiotika and used this term only a couple of times, referring to a specific sphere of semiosis that deals with regularized forms of behavior (Lotman 1976, 292-293). At the same time, as a recent reconstruction developed by Suren Zolyan suggests (Zolyan 2017), Lotman did theorize a great deal on social semiotic problems, emphasizing that "structural-ideological analysis" is a necessary component of semiotic analysis (Lotman 1963, 46). In his studies, which were mostly focused on literary texts, Lotman demonstrated that purely linguistic analysis that does not explore "ideological structures" is often insufficient when it comes to understanding meanings of texts, as texts are coded based on multiple co-functioning modelling systems that are the primary modelling system of natural language and the secondary modelling systems of culture, myth, religion, literature, art etc. (Lotman 1998, 21-22). Thus, the Tartu-Moscow School of the semiotics of culture seems in this respect very similar to the Hallidayan tradition of social semiotics, as it also focuses on the fact that linguistic meaning is usually supplemented with cultural or social meanings (Zolyan 2017, 130; see also Zolyan 2018, 2019).

In recent decades, Lotman's insights were critically interpreted and further developed into more systematic theories of social semiosis in the works of Anti Randviir who proposed a number of important concepts that build on the Tartu-Moscow semiotic tradition, but appear crucial for the development of social semiotics (sociosemiotics ${ }^{4}$ ) in general. Moreover, they can be seen as important amendments to Hodge's and Kress's Social Semiotics. In particular, in his 2004 work Mapping the World: Towards a Sociosemiotic Approach to Culture Randviir went beyond just focusing sociosemiotic analysis on the totality of anthroposemiosis, and problematized the borderline between realities that are semiotised and non-semiotised, as well as between reality that is cultural and non-cultural (Randviir 2004). He did so by situating human semiosis in the systematics of modelling systems, critically developing some of the concepts of Lotmanian semiotics of culture (e.g.: Lotman 1984, 1990, 1998) and biosemiotics (von Uexküll 1982; Sebeok 1991, 2001). In particular, he emphasized that "the origin of cultural sign systems lies in man's needs and abilities of modelling his environs as a biological being, and the creation of Umwelt" (Randviir 2004, 72, original emphasis), but natural language cannot be regarded as the primary system of such modelling (contrary to what

\footnotetext{
3 ''Social semiotics' can refer to two related but distinct entities. 'Social semiotics' without capitals is a broad, heterogeneous orientation within semiotics, straddling many other areas of inquiry concerned, in some way, with the social dimensions of meaning in any media of communication, its production, interpretation and circulation, and its implications in social processes, as cause or effect. 'Social Semiotics' with capitals is a distinguishable school in linguistics and semiotics which specifically addresses these issues" (Hodge, n.d.)

4 In this article social semiotics (non-capitalized) and sociosemiotics are used as synonyms, even though sometimes these two labels are distinguished (Cobley, Randviir 2009, 1).
} 
Yuri Lotman had suggested (cf. Lotman 1998, 21-22)). According to Randviir, the primary modelling of the world is not performed by natural language, but consists in the construction of Homo sapiens's species-specific Umwelt that has to be created in the intersection of the humans' biological needs and their environment. In other words, the Umwelt of humans is constructed prior to modelling the world with language, so the language models not the physical reality, but a reality that has already been semiotised. Thus, cultural semiotisation appears as the tertiary modelling system, following the secondary modelling system that is language and primary modelling system that is cognitive imaging of the world (Randviir 2004, 73-74).

Such differentiation of modelling systems suggests that cultural reality is surrounded by an expanse which is semiotised, but non-cultural. For the realm of cultural semiosis to emerge it has to be activated by "a certain amount of individuals whose interaction and usage of the same cultural units and semiotic institutions allows to see them as social groups" (Randviir 2004, 77). That is why semiotic analysis has to become socio-semiotic, i.e. taking into account social groups that perform the cultural semiotisation and institutions that function as "regulators of social and cultural processes" and contribute to the reproduction of semiotic reality through socialization (Randviir 2004, 78, 144).

Randviir's distinction of modelling systems, as well as his detailed theorization of the processes of semiotisation and cultural activation, has allowed him to develop a program of social semiotic research which not only defines its broad scope (all the human semiosis), but also captures the dynamism of its object. In particular, such dynamism is manifested in how Randviir formulates the goal of sociosemiotic analysis, saying that it "must centre at the manifestation of the relation between the reality that has been semiotised and that has not" (Randviir 2004, 71), as well as at the studies of "the reflective thought through which bearers of a culture become aware of their sociocultural reality and sign systems" (Randviir 2004, 63).

Another one of Randviir's achievements consists in positioning social semiotics among other semiotic and social disciplines. The distinction of modelling systems plays a crucial role in this respect as it clarifies how sub-domains of semiotics such as biosemiotics, linguistic semiotics, and cultural semiotics are built into the sociosemiotic framework. Moreover, Randviir outlines how sociosemiotics relates to the toolkits of other social and semiotic disciplines. According to his perspective, sociosemiotic research "should include the methods of all disciplines that allow the study of the different levels of sign production and exchange" (Randviir 2004, 45).

Even though in terms of its origin Randviir's project of the "sociosemiotic approach to culture" significantly diverges from Hodge's and Kress's Social Semiotics, in a way, it can be seen as a framework which complements it. In particular, Randviir's account of institutions that regulate cultural semiotisation can be seen as an important addition to Hodge's and Kress's concept of logonomic systems. With the inclusion of such institutions into the general framework of social semiotics it becomes more consistent, as it includes institutions as social forms and sign systems as semiotic forms, which are then mediated by logonomic systems as regulatory instances between the two. Moreover, in its social-theoretical aspect, Randviir's approach conceptualizes social interactions with the emphasis on collective goal-oriented activity (Randviir 2004, 58-59, 74-75). In this respect, his framework can be seen as an alternative to Hodge's and Kress's logic of power and solidarity (Hodge, Kress 1988,266$)$ and a potential interdisciplinary gateway to various social theories.

Furthermore, it may turn out productive to relate Randviir's concept of multiple modelling systems to the concept of multimodality developed in the systemic-functional tradition of Social Semiotics. In a way, both frameworks are based on the same principle of the emergence of sociosemiotic phenomena from a multiplicity of semiotic systems. But while, in the systemic functional school, the multiplicity of modes is usually regarded as a multiplicity of independent semiotic resources that, when combined, all contribute to a particular multimodal text, Randviir shows that there also exists an aspect in which some semiotic (modelling) systems construct separate semiotic realities that are then modelled by other semiotic (modelling) systems.

Summing up, the main achievement of Randviir's work can be seen in his attempt to provide a more nuanced and dynamic understanding of the object of social semiotic analysis. While Hodge and Kress mostly just declared that social semiotics deals with all the instances of human semiosis, Randviir succeeds in pointing out how human semiosis emerges, what modelling capacities enable it, and how the borderline between sociocultural semiosis and other aspects of human semiosis works. Furthermore, Randviir's contribution is important as he clarifies how social semiotics relates to other social and semiotic disciplines and outlines how other semiotic fields can be built into it, as well as claiming that sociosemiotic analysis should include tools from other disciplines. In this respect, however, his framework also brings new challenges as the task of actually importing the methods of all relevant disciplines into social semiotics is far from trivial. In a way, Risto Heiskala's work, discussed below, can be seen as just such an attempt.

\section{MODELLING INTENTIONAL SOCIAL ACTIONS IN SEMIOTIC SOCIOLOGY}

So, the last social-semiotic interface that is to be discussed in this article is the project of semiotic sociology developed by Risto Heiskala who presents a synthesis of Saussurean semiology, Peircean semiotics, Weberian 
social action theories, and Schütz's phenomenological sociology. In his book Society as Semiosis, which appeared in 2003, Heiskala was able to demonstrate how semiotic and sociological disciplines can complement each other and compensate each other's deficiencies, and, in particular, how the phenomenological tradition of studying meaningful behavior and intentional acts can be bridged with the Saussurean and Peircean traditions of studying acts of semiosis (Heiskala 2003).

One of the starting points for Heiskala's study was the review of how sociological theories evolved in terms of dealing with the problem of defining the concept of meaning. In particular, he recounts Weber's view that behavior qualifies as meaningful only when it is structured with "the categories of 'end' and 'means'"' (Weber 2007, 59). (It is only behavior of this kind that Weber had called action (Weber 1985, 542).) Contrastingly, in Schütz's phenomenological sociology, Weber's ideas were critically revisited and the understanding of action and meaning changed. In particular, action was defined as "the execution of a projected act" and the meaning of any action was conceptualized as the action's "corresponding projected act" (Schutz 1967, 61). Thus, from the phenomenological perspective, social reality appeared not as Weberian chains of means-and-ends, but rather as series of reflective intentional acts directed either at the past ("interpretations") or at the future ("projects") (Heiskala 2003, 82; Heiskala $2014,46)$. The model of means-and-ends chains was still relevant for social phenomenology, but turned out to be limited to the models of rational action (that is defined as the action that "requires, besides projecting, an explicit analysis of the causal connections") (Heiskala 2003, 82).

As Heiskala put it, the introduction of the phenomenological approach to meaning and action made it possible for the social scientists "to expand considerably the area of the study of society" (Heiskala 2014, 46). At the same time, however, as he insists, even with the phenomenological categories the social scientists' toolkit is still not complete. In particular, the existing sociological tools are unable to deal properly with non-reflective intentional acts, i.e. with the meanings that have not been explicated in the form of everyday knowledge. And this is exactly where the conceptual toolkit of semiotics would be promising.

In his project of semiotic sociology, Heiskala proposed to bridge the action-theoretical sociological frameworks and phenomenological sociology with the approaches of semiotics. As the key element of the conceptual interface integrating sociological and semiotic elements Heiskala suggested to use the notion intentional act that is central for sociology, but can be modelled properly based on the schemes borrowed from semiotics. Semiotic categories, according to Heiskala, belong to the base level of sociological meaning-analysis in a sense that they are applicable to the broadest range of types of acts, in contrast to the categories of phenomenological sociology which have a narrower scope and action-theoretical categories which are even more limited. In other words, action-theoretical, phenomenological, and semiotic approaches relate to each other in a cumulative way: "phenomenological sociology covers all problems formulated in action theory and neostructuralist ${ }^{5}$ semiotics covers all problems formulated in phenomenological sociology" (Heiskala 2014, 49).

According to Heiskala, both Saussurean and Peircean semiotic models can be effectively used as models of intentional acts (Heiskala 2014, 46) and importing those models into the apparatus of sociology will allow to broaden its scope, since the sphere of social meaning-making will not be restricted exclusively to reflective intentional acts anymore. In other words, with semiotics' conceptual toolkit, phenomenological sociology does not have to focus only on everyday knowledge. Furthermore, the use of the categories of semiotics liberates phenomenological sociology from the 'metaphysics of presence', i.e. from being "compelled to define meaning as a relationship between the consciousness and a sign, which is present, in the sense that it appears to the consciousness" (Heiskala 2014, 47). Instead, structuralist semiotics introduces, in addition to the act of appearance of the sign to the consciousness, the paradigmatic and syntagmatic relations that the sign has to other signs (Heiskala 2014, 47).

In general, Heiskala's project of semiotic sociology is an important contribution to the development of social semiotics, as it demonstrates that the attempts to systematically bridge semiotic and sociological studies can be undertaken not only in the domain of semiotics, but in the domain of social science as well. Furthermore, semiotic sociology can be seen as one of the most advanced attempts to really approach not just explicitly communicational interactions, but all social actions as acts of semiosis. ${ }^{6}$

Moreover, what makes Heiskala's project groundbreaking is his pioneering attempt to bridge Husserl's (and Schütz's) phenomenology with Peirce's pragmaticist phaneroscopy. Such integration is crucial in terms of its methodological implications, as it outlines how phenomenological social-theoretical concepts can be integrated into semiotic analyses. At the same time, there is also a challenging question that can hardly be avoided when speaking about Heiskala's semiotic sociology. The question is whether phenomenological sociology has to be the only region in which sociology and semiotics can be consistently integrated. Heiskala's own work hints that there may be other such regions. In particular, another such interface may appear in the domain of semiotic

\footnotetext{
5 Heiskala introduces guidelines for a "neostructuralist" version of semiotics as an amended version of main structuralist commitments. The proposed framework seeks to be more effective in accounting for the changes in structures, as well as for "situationally creative use of coded meanings" (Heiskala 2014, 36-41).

6 A similar approach was proposed in (Zolyan 2017; 2018; 2019).
} 


\section{TWO FRONTIERS OF SOCIAL SEMIOTICS IN RETROSPECTION}

In the previous sections of this article I analyzed the achievements and challenges of three distinct projects of systematic integration of the semiotic and the social. Summing up this analysis, I suggest that the development of the synthetic domain of sociosemiotic studies can be represented as trajectories of two frontiers of social semiotics which are the frontier of sociosemiotic material and the frontier of sociosemiotic methodology. In particular, the movement of the frontier of sociosemiotic material represents the development of social semiotics "from the point of view of social semiotics", focusing on how social semiotics broadens its scope through (re)defining, problematizing, and extending the set of material that is considered as an object of sociosemiotic analysis. In contrast, the dynamics of the frontier of sociosemiotic methodology describes the evolution of sociosemiotic approaches "from the point of view of social studies", i.e. in the aspect of how semiotic tools are integrated with other sociological methodologies. The trajectories of both frontiers can be considered both retrospectively and prospectively.

Retrospectively, when it comes to the frontier of sociosemiotic material, one can see that in recent decades semiotic studies made significant progress. In particular, the frontier moved forward from the Hallidayan phase of language as social, through the phase of semiotic as social pioneered by Hodge and Kress, towards the current phase of semiotic as multimodally socially semiotised. In each of these phases a particular extension of the material of sociosemiotic analysis was achieved. First, the material of linguistic analysis was extended to grasp not only referential, but social meanings, then the frontier was extended beyond language, thus grasping all other sign systems used by humans. Finally, in the current stage, sociosemiotic theories are becoming more sensitive to the dynamics of semiotisation, i.e. to how, from the interplay of different modes/modelling systems, semiotised realities emerge.

At the same time, the progress on the frontier of sociosemiotic methodology has been less impressive. While the example of the project of "semiotic sociology" does show that systematic integration of semiotic tools into the sociological toolkits is in fact possible (and even necessary) (Heiskala 2003, 2014), the actual frameworks which appear from such integration are far from becoming a part of sociological mainstream. What may be seen as a counterexample, as a "success story" of sociosemiotic methodology, is the situation with "multimodality studies", which, deriving from Social Semiotics, did succeed in developing into a popular sociological current. The popularity, however, came with a price, as the whole apparatus of Social Semiotics was more or less reduced to just one concept. (In this respect, the case of multimodality seems similar to that of structuralism, as in the second half of the 20th century there was definitely some superficial progress in terms of (post) structuralist "semiotisation" throughout all social sciences and many of them were to some degree influenced by structuralist and post-structuralist thought. But not that much has actually been done in terms of deep systematic integration of social and semiotic methodologies that would go beyond using some separate (post)structuralist concepts and interpretive frameworks.) Ultimately, what remains unsolved is the challenge of developing a sociosemiotic framework that is both systematic, in terms of its connections to a fundamental semiotic toolkit, and penetrative, in terms of actually being used in social studies.

\section{TWO FRONTIERS OF SOCIAL SEMIOTICS IN PROSPECTION}

As I have already mentioned above, the distinction and tracing of the two frontiers of social semiotics can be productive not only in terms of retrospectively analyzing the achievements of social-semiotic convergence, but also in terms of prospectively outlining future challenges and opportunities. So, the question that I want to pose in the final section of this article is: what can be the next steps on the trajectories of the frontier of sociosemiotic material and the frontier of sociosemiotic methodology?

As to the frontier of sociosemiotic material, I suppose that here future progress can involve a transition to the phase of social as semiotic. This would imply that contemporary social semiotics' focus on multimodality is to be supplemented with the focus on multiactionality, i.e. social semiotic analysis will have to be able to consider as sociosemiotic modes not only various resources of communication, but also different spheres of social action. First steps in this direction were already made in "semiotic sociology", which suggested to systematically model intentional acts as acts of semiosis (Heiskala 2003, 2014) and to synthesize semiotics with Parsons's and Habermas's structural-functionalism. ${ }^{7}$ Some of the recent interpretations (Zolyan 2017, 2018, 2019) of the Tartu-Moscow School's ideas about the semiotics of action (semiotics of behavior) (Lotman 1967; Lotman 1975a, 26, 38-39; Lotman 2008; Pyatigorski, Ouspenski 1967; Piatigorsky, Uspensky 1975) also hint that such progress is possible. Furthermore, a similar trend is already noticeable in microsociological research, as one can observe a convergence of multimodality studies

\footnotetext{
7 Heiskala suggests that such synthesis may provide a framework in which the distinction between social subsystems ("economic system", "administrative system" and "lifeworld") would correspond to the semiotic distinction between different signs ("monetary signs" (the constraints of scarcity), "legal signs" (the constraints of organized violence) and "ritually affirmed symbols" (communicative constraints)) (Heiskala 2007).
} 
with the analysis of multiactivity (Haddington et al. 2014; Jewitt et al. 2016, 95).

Another prospective extension of social semiotic material, I think, can be achieved by a more systematic investigation of social semiotic as habitual (here I refer to the Peircean concept of Habit, meaning any "general rule operative within the organism" [W 4:249] (Peirce $1982,249)$ ). Such focus will in fact imply studying semiotic systems as social institutions and social institutions as semiotic systems. Some progress in this direction has already been made in theorizations on logonomic systems (Hodge, Kress 1988, 4), semiotic institutionalism (Heiskala 2007), semiotics of regularized behavior (Pyatigorski, Ouspenski 1967, 28; Lotman 1975a, 25-26; Lotman 1976, 292-293; Chernov 1967; Zolyan, Chernov 1977; Zolyan 2017, 2018, 2019), and other ideas about studying sign systems as institutions (e.g.: Randviir, 2004, 40, 56-59, 72).

Finally, one also cannot ignore the fact that although social semiotics declares that it studies all the anthroposemiotic phenomena, actually today it is almost exclusively focused on microsociological analysis. So, an important prospective direction for expanding the actual material of social semiotics could be the development of methods that make it possible to study temporally protensive and spatially extensive social events. (An attempt to develop a social semiotic toolkit of this kind was made in the project of multimodal analysis of political performatives (Ilyin 2016a, 2016b; Fomin 2016; Efimova et al. 2016; Alekseev et al. 2016).)

When it comes to the prospection for the frontier of sociosemiotic methodology, the central question that will have to be faced in the future has already been mentioned above. How can a sociosemiotic framework emerge that will be both systematic in terms its fundamental semiotic tools and penetrative in terms of actually becoming a part of the apparatus of social studies? At this point, it is quite difficult for me to give a certain answer, however, I can name two trajectories that do seem promising. Those trajectories can be called social semiotics as social functionalism and social semiotics as social interpretivism. What I mean by this is that, first of all, one can imagine a productive integration between two domains of functionalism which are the systemic functionalism of Social Semiotics and structural functionalism in sociology. ${ }^{8}$ Second, social semiotics can definitely be more deeply integrated with the whole range of interpretive approaches and qualitative methods used in social studies, as semiotics does have all the potential to become a fundamental element of an integrated transdisciplinary interpretivist methodology.

For now, both the projects of social semiotics as social functionalism and social semiotics as social interpretivism are somewhat underdeveloped. Their realization will require a lot of effort in terms of finding connecting links between sociological and semiotic toolkits. One example of such link is the parallelism between the semiotic models of sign and sociological models of intentional acts. Hopefully, more attempts to develop such conceptual interfaces will follow. Furthermore, the progress of the methodological frontier of social semiotics relies in a large extent not only on theoretical developments, but also on proper design of syllabi in social studies. Social semiotics must become an essential transdisciplinary component of methodological courses for future social scientists.

Ultimately, both in the frontier of sociosemiotic material and the frontier of sociosemiotic methodology there is still a lot of challenges to be resolved. However, the final destinations of the trajectories of both frontiers are more or less clear. The final point in the progress of the frontier of sociosemiotic material will be a sociosemiotic framework that will be able to (both statically and dynamically) grasp, distinguish, and relate to each other all the various semiotic and social forms, regardless of their temporal and spatial scale, multimodal complexity, and anisomorphism. As to the destination point of the methodological frontier, social semiotics is to become a "coenoscopic antidote" (Deely 2015, 3) integrating the nebula of diverse interpretive tools used in social studies.

\section{ACKNOWLEDGMENTS}

I would like to show my gratitude to Mikhail Ilyin, Tyler James Bennett, and Mark Pharoah for their valuable comments and suggestions during the development of this work.

\section{FUNDING}

This study was supported by the Russian Science Foundation (grant project number: 17-18-01536).

\section{REFERENCES}

Alekseev, D. et al., 2016. Kto i kak zakonchil Vtoruiu mirovuiu voinu? $=$ Who and how has end[ed] the Second World War? Politicheskaia nauka = Political Science (RU), 2016(4), 299-316.

Austin, J. L., 1962. How to do things with words. Toronto; Buffalo; London: Clarendon Press.

Barthes, R., 1957. Mythologies. Paris: Éditions du Seuil.

Caldas-Coulthard, C. R., Coulthard, M. (Eds.), 1996. Texts and practices: Readings in critical discourse analysis. London; New York: Routledge.

Chernov, I., 1967. O semiotike zapretov (predvaritel'noe soobshchenie) = Semiotic Aspects of Interdiction. Trudy po znakovym sistemam $=$ Works on Semiotics [= Sign Systems Studies], 3, 45-59.

Cobley, P., Randviir, A., 2009. Introduction: What is

8 A preliminary attempt to inventory various functionalisms and to relate them to social semiotics was presented in (Fomin, Ilyin, 2019). 
sociosemiotics? Semiotica, 2009(173), 1-39.

Deely, J., 2015. Semiotics "Today": The Twentieth-Century Founding and Twenty-First-Century Prospects. In Trifonas, P. P. (Ed.), International handbook of semiotics. Dordrecht: Springer, pp. 29-113.

Efimova, E. et al., 2016. Kto i kak nachal Pervuiu mirovuiu voinu? = Who and how did start the First World War? Politicheskaia nauka = Political Science $(R U)$, 2016(4), 285-298.

Fomin, I. V., Ilyin, M. V., 2019. Sotsial'naia semiotika: traektorii integratsii sotsiologicheskogo i semioticheskogo znaniia = Social Semiotics: Paths towards Integrating Social and Semiotic Knowledge. Sotsiologicheskij Zhurnal = Sociological Journal, 25(4), 123-141.

Fomin, I., 2016. Performativy setsessii osparivaemykh gosudarstv: Iuzhnaia Osetiia, Abkhaziia, Kosovo = Performatives of secession of contested states: South Ossetia, Abkhazia, Kosovo. Politicheskaia nauka = Political Science (RU), 2016(4), 271-284.

Foucault, M., 1966. Les mots et les choses: Une archéologie des sciences humaines. Paris: Gallimard.

Haddington, P., Keisanen, T., Mondada, L., Nevile, M. (Eds.), 2014. Multiactivity in social interaction: Beyond multitasking. Amsterdam: John Benjamins Publishing Company.

Halliday, M. A. K., 1978. Language as social semiotic: The social interpretation of language and meaning. London: Arnold.

Halliday, M. A. K., 2007. Language as Social Semiotic: Towards a General Sociolinguistic Theory (1975). In Halliday, M. A. K. Language and Society: Volume 10 (1st ed.). London: Bloomsbury Academic, pp. 169-202.

Heiskala, R., 2003. Society as semiosis: Neostructuralist theory of culture and society. Frankfurt am Main; New York: Peter Lang.

Heiskala, R., 2007. Economy and society: From Parsons through Habermas to semiotic institutionalism. Social Science Information, 46(2), 243-272.

Heiskala, R., 2014. Toward semiotic sociology: A synthesis of semiology, semiotics and phenomenological sociology. Social Science Information, 53(1), 35-53.

Hodge, B., n.d. Social Semiotics. In Bouissac, P. (Ed.) Semiotics Encyclopedia Online, available at: <http://projects.chass.utoronto.ca/semiotics/dse/S/social_semiotics.html\#>

Hodge, R., Kress, G., 1988. Social Semiotics (1st edition). Ithaca, N.Y.: Cornell University Press.

Ilyin, M., 2016a. Chto mozhet dat' analiz performativov? = What can give analysis of performatives? Politicheskaia nauka = Political Science (RU), 2016(4), 262-270.

Ilyin, M., 2016b. Idei i praktika: Mul'timodal'nyi analiz politicheskikh performativov. Politicheskaia nauka $=$ Political Science (RU), 2016(4), 261

Jewitt, C., Bezemer, J., O’Halloran, K., 2016. Introducing Multimodality. London; New York: Routledge.
Kress, G., van Leeuwen, T., 1996. Reading Images: The Grammar of Visual Design. London; New York: Routledge.

Kress, G., van Leeuwen, T., 2001. Multimodal discourse: The modes and media of contemporary communication. London; New York: Arnold; Oxford University Press.

Lotman, Iu. M., 1963. O razgranichenii lingvisticheskogo i literaturovedcheskogo poniatiia struktury. Voprosy lazykoznaniia [= Topics in the study of language], XII(3), 44-52.

Lotman, J., 1967. K probleme tipologii kul'tury = About the Problem of Cultural Typology. Trudy po znakovym sistemam $=$ Works on Semiotics [= Sign Systems Studies], 3, 30-38.

Lotman, lu. M., 1975a. Dekabrist v povsednevnoi zhizni (Bytovoe povedenie kak istoriko-psikhologicheskaia kategoriia). In Bazanov, V. G., Vatsuro, V. E. (Eds.), Literaturnoe nasledie dekabristov. Leningrad: Nauka, Leningradskoe otdelenie, pp. 25-74.

Lotman, Iu. M., 1975b. O Khlestakove. Trudy po russkoi i slavianskoi filologii, XXVI, 19-53.

Lotman, Iu. M., 1976. Bytovoe povedenie i tipologiia kul'tury v Rossii XVIII v. In Bazanov, V. G. (Ed.), Kul'turnoe nasledie Drevnei Rusi. Istoki. Stanovlenie. Traditsii: [K 70-letiiu D. S. Likhacheva]. Moscow: Nauka, pp. 292-297.

Lotman, Iu. M., 1984. O semiosfere. Trudy po znakovym sistemam $=$ Works on Semiotics [=Sign Systems Studies], 7, 5-23.

Lotman, Y. M., 1990. Universe of the mind: A semiotic theory of culture. Bloomington; Indianapolis: Indiana University Press.

Lotman, lu. M., 1998. Struktura khudozhestvennogo teksta. In Lotman, Iu. M. Ob iskusstve. Saint Petersburg: Iskusstvo-SPB, pp. 14-285.

Lotman, J., 2008. Neskol'ko vvodnykh slov = A few introductory words. Sign Systems Studies, 36(2), 509-512.

Morris, C., 1938. Foundations of the Theory of Science. Illinois: University of Chicago.

Peirce, C. S., 1982. Writings of Charles S. Peirce: A chronological edition: Vol. 4: 1879-1884. Bloomington: Indiana University Press.

Piatigorsky, A. M., Uspensky, B. A., 1975. Personological Classification as a Semiotic Problem. Semiotica, 15(2), 99-120.

Pyatigorski, A., Ouspenski, B., 1967. Personologicheskaia klassifikatsiia kak semioticheskaia sistema = Personological Classification as a Semiotic Problem. Trudy po znakovym sistemam $=$ Works on Semiotics [ $[=$ Sign Systems Studies], 3, 7-29.

Randviir, A., 2004. Mapping the world: Towards a sociosemiotic approach to culture. Saarbrücken: Lambert Academic Publishing.

Saussure, F. de., 1995. Cours de linguistique générale. Paris: Payot.

Schutz, A., 1967. The phenomenology of the social world. Evanston: Northwestern University Press. 
Searle, J. R., 1989. How Performatives Work. Linguistics and Philosophy, 12(5), 535-558.

Sebeok, T. A., 1991. In what sense is language a "primary modeling system." In Anderson, M., Merrell, F. (Eds.) On Semiotic Modeling. Mouton de Gruyter, pp. 327-340.

Sebeok, T. A., 2001. Signs: An Introduction to Semiotics (2nd ed.). Toronto; Buffalo; London: University of Toronto Press.

von Uexküll, J., 1982. The Theory of Meaning. Semiotica, 42(1), 25-82.

Weber, M., 1985. Gesammelte Aufsätze zur Wissenschaftslehre. Tübingen: Mohr.

Weber, M., 2007. Objectivity and Understanding in Economics. In Hausman, D. M. (Ed.), The Philosophy of Economics: An Anthology (3rd ed.). Cambridge: Cambridge University Press, pp. 59-72.

Wittgenstein, L., 1986. Philosophical investigations. Oxford: Blackwell.
Zolyan, S., 2017. Iurii Lotman i sotsial'naia semiotika: $\mathrm{K}$ postanovke problemy $=$ Juri Lotman and Social Semiotics: Paths for New Research. Zbornik Matitse Srpske za slavistiku = Matica Srpska Journal of Slavic Studies, 92, 123-150.

Zolyan, S. T., 2018. K probleme smysla v sotsial'noi semiotike: Maks Veber segodnia = The problem of meaning in Social Semiotics: Max Weber today. Slovo. ru: baltijskij accent, 9(4), 27-42.

Zolyan, S., 2019. General Sociolinguistics, Social Semiotics and Semiotics of Culture - Ex Pluribus Unum? Sign Systems Studies, 47(3-4), 400-419.

Zolyan, S., Chernov, I., 1977. O strukture iazyka opisaniia povedeniia $=$ About the structure of the language of behaviour description. Trudy po znakovym sistemam [= Sign Systems Studies], 8, 151-163.

Return to front page $\uparrow$ 